\title{
Media Kesehatan Masyarakat Indonesia
}

Volume 16 Issue 22020

DOI : $10.30597 /$ mkmi.v16i2.9047

Website : http://journal.unhas.ac.id/index.php/mkmi

(C) 2020 by author. This is an open access article under the CC BY-NC-SA license

\section{Analisis Survival pada Penderita Gagal Ginjal Kronik dengan Komorbiditas Diabetes Melitus}

\section{Survival Analisis of Chronic Kidney Disease with Coomorbidity Diabetes Melitus}

\author{
Nova Muhani ${ }^{*}$, Nurhalina Sari ${ }^{1}$ \\ 1FKM Universitas Malahayati Bandar Lampung \\ *Email korespondensi : muhaninova@gmail.com
}

\section{ARTICLE INFO}

\section{Article History:}

Received Feb, 2 ${ }^{\text {nd }}, 2020$

Revised form Apr, 30 3020

Accepted Jun, $12^{\text {th }}, 2020$

Published online Jun, 29th 2020

\section{Kata Kunci:}

Analisis survival;

PGK;

diabetes melitus;

\section{Keywords:}

Analysis survival;

CKD;

diabetes mellitus;

\begin{abstract}
ABSTRAK
Penyakit Ginjal Kronis (PGK) merupakan masalah kesehatan masyarakat global dengan prevalensi dan insiden gagal ginjal yang terus meningkat, PGK merupakan penyebab kematian secara global, penyebab PGK terbesar adalah komorbiditas dengan diabetes melitus. Kematian tertinggi terjadi pada 6-12 bulan pertama menjalani hemodilaisa yaitu sebesar $33 \%$. Tujuan penelitian mengetahui umur, jenis kelamin, kadar hemoglobin, dan lama ketahanan hidup pasien PGK yang disertai diabetes melitus. Desain penelitian kohort prospektif, sampel sebesar 159 responden. Penelitian menggunakan data dari laporan harian unit hemodialisis Rumah Sakit Umum Daerah Dr. Abdul Moeloek (RSUDAM) Lampung yaitu pasien baru yang menjalani hemodialisis kemudian dilakukan observasi selama 12 bulan. Analisis yang digunakan ialah analisis survival dengan cox regression. Hasil penelitian menunjukan ratarata lama ketahanan hidup 5 bulan, terjadi kematian (event) sebesar 47,8\%, pasien PGK dengan komorbiditas diabetes melitus 27,7\%. Responden hemodialisa berdasarkan jenis kelamin laki-laki (51\%) dan perempuan (49\%), umur kurang dari 60 tahun 64,4\%, kadar hemoglobin kurang dari 7 mg\% (anemia berat) 28,4\%. Hasil uji statistik diperoleh jenis kelamin $p=0,602$, umur $p=0,582$, anemia $p=0,567$, dan riwayat diabetes melitus ( $p=0,001$, dengan $\alpha=0,05$, (Risk Ratio=2,3) kelompok tidak diabetes melitus memiliki ketahanan hidup 2,3 kali lebih tinggi dibandingkan kelompok diabetes melitus. Pasien PGK dengan penyakit penyerta diabetes sebaiknya lebih menjaga kesehatan dengan diet protein dan mengontrol kadar gula darah.
\end{abstract}

\section{ABSTRACT}

Chronic Kidney Disease (CKD) is a global public health problem with an increasing prevalence and incidence of kidney failure a poor prognosis and high treatment costs. CKD is the leading cause of death the global, the biggest cause of CKD is coomorbidity with diabetes mellitus. the highest mortality occurred in the first 6-12 months undergoing hemodynamic which is 33\%. The purpose of this study was to determine the age, sex, hemoglobin level, and survival time of CKD patients undergoing hemodialysis based on diabetes mellitus coomorbidity. The study desain was a prospective cohort, with sample of 159 respondents. The study used data from the daily report of the hemodialysis unit Abdul Moeloek Hospital in Lampug Province, responden is a new patients undergoing hemodialysis were then observed for 12 months. The analysis used survival analysis with cox regression. The results showed an average survival of 5 months, death occurred (event) by 47.8\%, patients with CKD with Diabetes mellitus comorbidity $27.7 \%$. Hemodialysis respondents type of female (55,3\%) and male (44,7\%), age less than 60 years 64.4\%, hemoglobin levels less than 7 mg\% (severe anemia) 28.4\%. Statistical test results obtained sex $p=0.602$, 
age $p=0.582$, anemia $p=0.567$, and a history of diabetes mellitus ( $p=0.001$ with $\alpha=0.05$, (Risk Ratio=2.3). CKD Patients comorbidities diabetes melitus they are should better maintain health with a protein diet and control blood sugar.

\section{PENDAHULUAN}

Permasalahan kesehatan di dunia yang masih menjadi prioritas adalah Penyakit Tidak Menular (PTM). Penyakit Ginjal Kronik (PGK) merupakan salah satu dari PTM, kasus PTM ini terus mengalami peningkatan dimana, penyebab tidak langsung dipengaruhi oleh tingginya tingkat stress, perubahan pola hidup yang pasif, pola konsumsi, seperti banyak mengonsumsi tinggi lemak dan kolesterol. ${ }^{1}$

Tahun 1990 PGK merupakan salah satu penyebab kematian dimana prevalensinya terus mengalami penigkatan dari peringkat ke-27 menjadi urutan ke-18 di dunia pada tahun 2010.2 Meningkatnya insiden dan prevalensi PGK adalah kesehatan yang serius menantang secara global. Ketahanan hidup dan faktorfaktor yang dapat berkontribusi pada umur panjang penyakit ginjal kronis pasien pada hemodialisis. ${ }^{3}$ Peningkatan prevalensi PGK seiring dengan meningkatnya jumlah penduduk usia lanjut dan kejadian penyakit diabetes melitus serta hipertensi. Prevalensi global PGK sebesar 13,4\%. ${ }^{4}$ penderita PGK berkisar antara 77-283 per satu juta penduduk dibeberapa negara. Beberapa negara maju seperti Jepang, Australia dan Inggris, sedangkan di Malaysia memperkirakan dari jumlah penduduk 18 juta terdapat 1800 kasus baru gagal ginjal pertahunnya. ${ }^{5}$
Laporan data Indonesia Renal Registry pasien baru yang menjalani hemodialisis dari 4977 pada tahun 2007 kemudian tahun 2015 menjadi 21050 pasien. Peningkatan kasus PGK sebanding dengan meningkatnya pasien yang menjalani hemodialisis. Pengobatan hemodialisis dikaitkan dengan penurunan risiko kematian dibandingkan dengan pengobatan konservatif. ${ }^{6}$ Faktanya prevalensi kematian pasien PGK yang menjalani hemodialisis masih tinggi, prevalesni tertinggi pasien yang menjalani hemodialisis 3 bulan sampai 12 bulan pertama yaitu dari 6,6\% sampai 74\%.7 Berdasarkan laporan Indonesia Renal Registry kematian tertinggi terjadi pada 612 bulan pertama menjalani hemodilaisa yaitu sebesar 33\%.8 Penelitian Umami didapatkan angka kematian sebesar $31,7 \%$ terjadi pada 3 bulan pertama pasien PGK yang menjalani hemodialisis. $^{9}$

RSUDAM merupakan salah satu rumah sakit pemerintah yang melaksanakan pelayanan hemodialisis di Provinsi Lampung. Berdasarkan survei yang dilakukan di unit hemodialisis dari tahun 2016-2018 masing-masing 238, 306, 332 hal ini menunjukkan jumlah pasien baru yang meningkat dari tahun ke tahun yang didiagnosis PGK yang menjalani hemodialisis. Seiring dengan meningkatnya kasus dan besarnya risiko kematian pasien PGK yang terjadi di RSUDAM Bandar Lampung. 
Meningkatkanya risiko kematian pasien PGK yang menjalani hemodialisis dengan adanya komordibitas. Komordibitas paling sering terjadi adalah hipertensi dan diabetes melitus. Secara etiologi, diabetes mellitus yang menahun menyebabkan komplikasi nefropati sehingga menyebabkan kelainan ginjal sekunder. ${ }^{10}$

Data laporan secara global, kasus PGK terbesar disebabkan oleh diabetes mellitus. Data yang dilaporkan di Indonesia sampai dengan tahun 2000, penyebab terbanyak adalah glomerulonefritis, tetapi beberapa tahun terakhir bergeser menjadi hipertensi berdasarkan laporan IRR tahun 2015, nefropati diabetik pada pasien diabetes melitus berkembang ke arah penyakit ginjal dan berakhir end stage renal disease sebanyak 10-21\%.11 Sebuah penelitian yang dilakukan di Iran, bertujuan mengetahui perbedaan lama ketahanan hidup 1 sampai 15 tahun pasien PGK yang menjalani hemodialisis lama ketahanan hidup pasien PGK dengan yang disertai diabetes mellitus lebih tinggi dibandingkan dengan tidak disertai diabetes mellitus dan lama ketahanan hidup tidak lebih dari 10 tahun. ${ }^{12}$ Tujuan penelitian ini untuk mengetahui satatus demografi (umur, jenis kelamin, status anemia,) dan lama ketahanan hidup pasien PGK yang menjalani hemodialisis yang disertai dengan diabetes mellitus.

\section{BAHAN DAN METODE}

Desain dalam penelitian ini menggunakan kohort prospektif dengan menggunakan data sekunder yaitu data dari laporan harian unit hemodialisis di RSUD Abdul Moeloek Bandar
Lampung, populasi dalam penelitian ini adalah pasien hemodialisis yang dimulai 01 Juli 2018 sampai 31 Desember 2019. Sampel mempunyai kriteria yaitu pasien baru yang menjalani hemodialisis yang terhitung tanggal dimulai 01 Juli 2018 sampai 30 Juni 2019. Sampel yang digunakan sebanyak 159 responden, teknik sampel yang digunakan mengguakan purposif sampling, dimana sampel dipilh berdasarkan kriteria yang telah ditentukan peneliti yaitu diagnosis penyakit ginjal kronik, memiliki usia lebih dari 18 tahun, menjalani hemodialisis selama penelitian berlangsung.

Analisis yang digunakan pada penelitian ini ialah analisis survival yaitu penggunaan kapplan meier serta permodelannya menggunakan uji regresi cox dengan asumsi proporsional hazard. Penggunaan kapplan meier dengan log rank untuk menilai probabilitas ketahanan hidup sedangkan regresi cox dimasukkan untuk mengestimasi Hazard Ratio (HR) menguji hipotesis dari HR dan melihat confident interval dan hasil disajikan dalam bentuk grafik survival function. Keterangan laik etik diterbitkan dari Komisi Etik Penelitian Kesehatan Universitas Malahayati No. 248/EC/KEP-UNMAL/I/2019.

\section{HASIL}

Terdapat 159 responden yang memenuhi kriteria inklusi. Karakteristik responden PGK dengan komorbiditas diabetes melitus bahwa terdapat $47,8 \%$ pasien meninggal, selama pengamatan 12 bulan yang mengalami diabetes melitus sebesar 27,7\%, dimana karateristik umur tertinggi adalah pasien dengan umur dibawah 60 tahun yaitu sebesar 76,1\%, jenis 
kelamin laki-laki 44,7\%, kadar hemoglobin tertinggi ialah pasien dengan kadar hemoglobin > 7gr\% sebesar 73\% (Tabel 1). Rata-rata lama ketahanan hidup pasien hemodialisis dengan PGK komorbiditas diabetes melitus di Rumah Sakit Umum Daerah Abdul Moeloek tahun 2018-2019 adalah dari 12 bulan pengamatan rata-ratanya adalah 4,9 bulan (Tabel 2).

Gambar 1 menjelaskan bahwa asumsi proporsional hazard terpenuhi, fungsi survival atau fungsi hazard variabel sudah proporsional dari waktu kewaktu. Kelompok tidak diabetes melitus memiliki survival rate yang lebih tinggi dibandingkan kelompok yang mengalami diabetes. Kejadian event dan jumlah sensor digambarkan pada plotting garis fungsi survival pada grafik Kaplan Meier digambarkan setiap waktu sesuai kejadian, pada kelompok diabetes melitus dan tidak diabetes melitus juga tergambar. Grafik tersebut tampak sensor terdapat pada kedua kelompok.

Tabel 1. Karakteristik Responden

\begin{tabular}{lcc}
\hline \multicolumn{1}{c}{ Karakteristik } & $\mathbf{n}=\mathbf{1 5 9}$ & $\mathbf{\%}$ \\
\hline Status & & \\
$\quad$ Hidup & 83 & 52,2 \\
$\quad$ Meninggal & 76 & 47,8 \\
Status Diabetes Melitus & & \\
$\quad$ Ya & 44 & 27,7 \\
$\quad$ Tidak & 115 & 72,3 \\
Umur (Tahun) & & \\
$\quad<60$ & 117 & 76,1 \\
$\quad$ > 60 & 38 & 23,9 \\
Jenis Kelamin & & \\
$\quad$ Perempuan & 88 & 55,3 \\
$\quad$ Laki-laki & 71 & 44,7 \\
Kadar Hemoglobin & & \\
$\quad>7 g r \%$ & 116 & 73,0 \\
$\quad<7 g r \%$ & 43 & 27,0 \\
\hline Sumber : Data Sekunder, 2018-2019 &
\end{tabular}

Tabel 2. Rata-Rata Lama Ketahanan Hidup Pasien Hemodialisis dengan PGK Komorbiditas Diabetes Melitus

\begin{tabular}{|c|c|c|c|c|}
\hline $\mathbf{n}$ & Min & Max & Mean & SD \\
\hline 159 & 1,00 & 12,00 & 4,99 & 3,74 \\
\hline
\end{tabular}

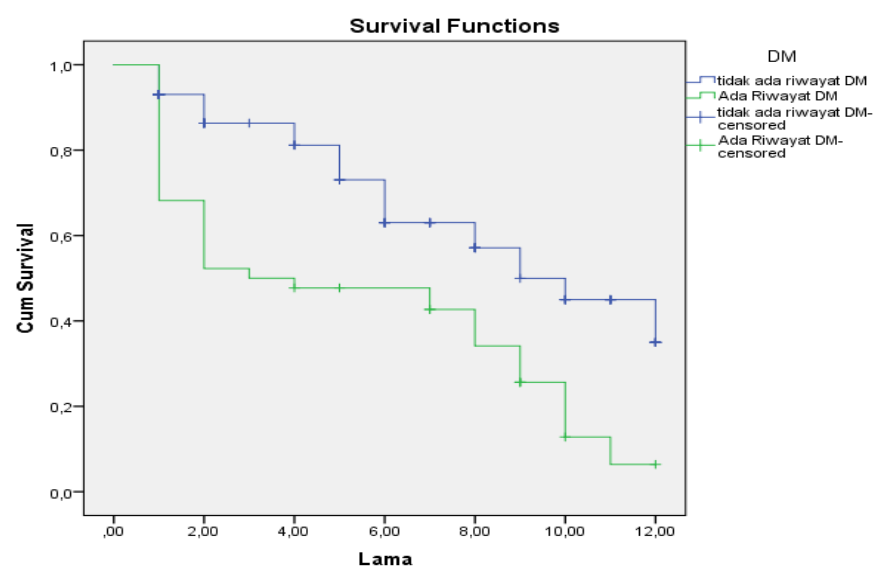

Sumber : Data Sekunder, 2018-2019

Gambar 1. Grafik Survival Function Status Diabetes Melitus dengan Lama Ketahanan Hidup Pasien PGK

Gambar 2 menjelaskan bahwa asumsi proporsional hazard tidak terpenuhi, fungsi survival variabel umur yang lebih dari 60 tahun dan kurang dari 60 tahun tidak proporsional dari waktu kewaktu.

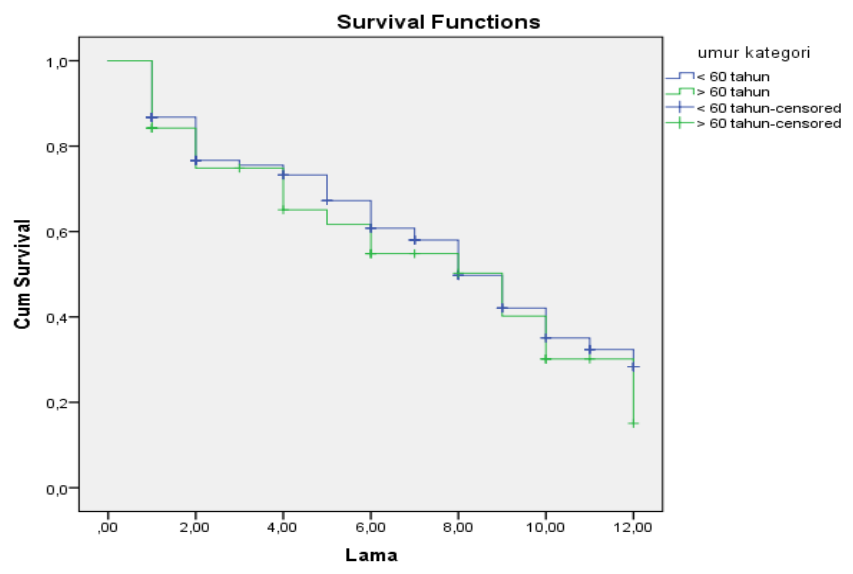

Sumber : Data Sekunder, 2018-2019

Gambar 2. Grafik Survival Function Umur dengan Lama Ketahanan Hidup Pasien PGK 
Asumsi proporsional hazard jenis kelamin anatara laki-laki dan perempuan tidak terpenuhi, fungsi survival variabel jenis kelamin tidak proporsional dari waktu kewaktu (Gambar 3). Berdasarkan Gambar 4, asumsi proporsional hazard hemoglobin dengan kadar kurang dari 7 mg\% dan yang lebih dari $7 \mathrm{mg} \%$ tidak terpenuhi, fungsi survival variabel kadar hemoglobin tidak proporsional dari waktu kewaktu.

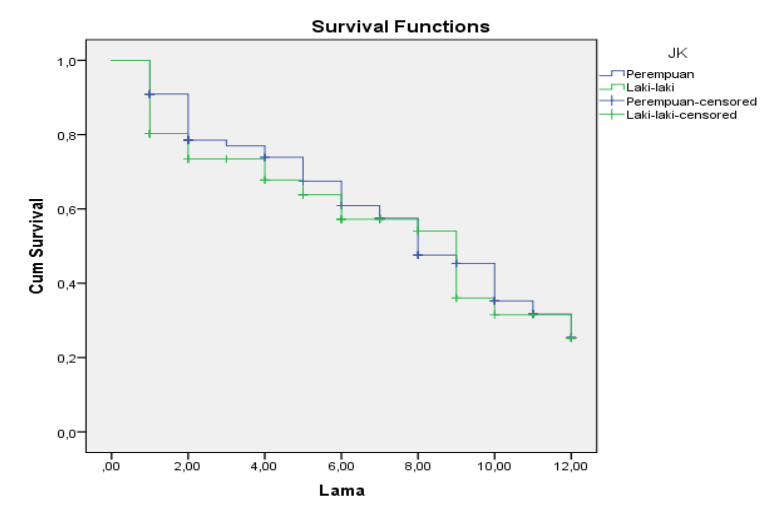

Sumber : Data Sekunder, 2018-2019

Gambar 3. Grafik Survival Function Jenis Kelamin dengan lama ketahanan hidup pasien PGK

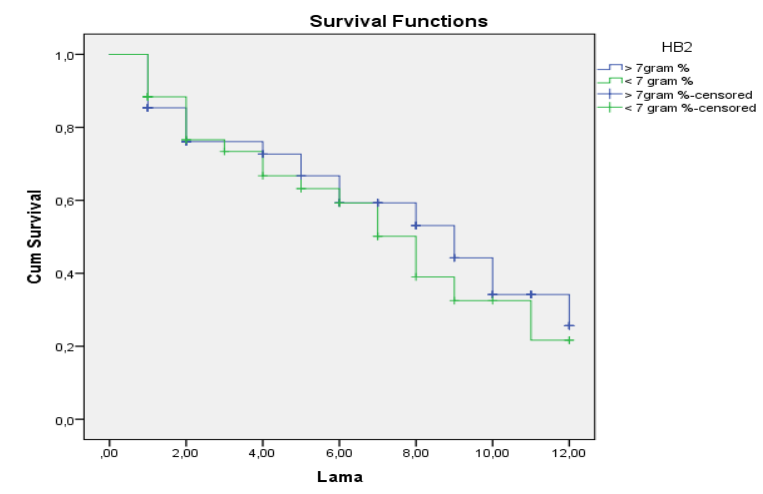

Sumber : Data Sekunder, 2018-2019

Gambar 4. Grafik Survival Function Kadar Hemoglobin dengan lama ketahanan hidup pasien PGK
Analisis menggunakan cox regression, variabel terdiri dari diabetes melitus, umur, jenis kelamin dan kadar hemoglobin, hanya variabel diabetes melitus yang asumsi proporsional hazard terpenuhi terlihat dari grafik survival dan hazard function. Hasil menunjukan bahwa variabel umur dengan nilai $p=0,582$, jenis kelamin 0,601 dan kadar hemoglobin dengan nilai $p=0,321(>0,05)$, variabel covariat tersebut tidak berhubungan dengan lama ketahanan hidup pasien PGK, sedangkan status diabetes melitus mempunyai nilai $p=0,001$ dengan risk rasio sebesar 2,3, artinya kelompok tidak diabetes melitus memiliki ketahanan hidup 2,3 kali lebih tinggi dibandingkan kelompok diabetes melitus. Kelompok tidak diabetes melitus memiliki waktu yang lebih lama untuk hidup dibandingkan dengan kelompok diabetes melitus (Tabel 3).

\section{PEMBAHASAN}

Sampel yang diamati selama 12 bulan sebanyak 159 responden bahwa terjadi kematian (event) sebesar 47\%, sedangkan yang hidup 53\% yaitu (sensor), hal ini dapat dijelaskan bahwa kematian pada pasien PGK banyak terjadi pada 12 bulan pertama, hal ini tidak jauh berbeda dengan laporan Indonesia Renal Register yang menjelaskan bahwa kematian PGK pada bulan ke satu sampai kurang dari tiga, hemodialisa sebesar 22\%, pada bulan ketiga sampai ke enam 18\% dan pada bulan ke enam sampai 12 bulan 33\% kalau kita jumlahkan maka kematian pasien PGK yang menjalani hemodialisa sampai bulan ke 12 sebesar $63 \%$. 
Tabel 3. Analisis Survival dengan Uji Cox Regression

\begin{tabular}{|c|c|c|c|c|c|}
\hline \multirow{2}{*}{ Variabel } & \multirow{2}{*}{$\boldsymbol{\beta}$} & \multirow{2}{*}{$p$} & \multirow{2}{*}{$\mathbf{R R}$} & \multicolumn{2}{|c|}{ Confident Interval } \\
\hline & & & & Lower & Upper \\
\hline Diabetes Melitus & 0,849 & 0,001 & 2,336 & 1,483 & 3,680 \\
\hline Umur & 0,141 & 0,582 & 1,152 & 0,696 & 1,906 \\
\hline Jenis Kelamin & 0,262 & 0,601 & 1,128 & 0,717 & 1,776 \\
\hline Kadar Hemoglobin & 0,321 & 0,567 & 1,162 & 0,696 & 1,941 \\
\hline
\end{tabular}

Sumber : Data Sekunder, 2018-2019

Terdapat 27,4\% pasien PGK dengan komorbiditas diabetes melitus, hasil ini tidak jauh berbeda dengan laporan IRR bahwa pe-nyakit penyerta pasien hemodialisis pada tahun 2015 dapat dilihat pada diagram, hipertensi masih merupakan penyakit penyerta terbanyak, dan disusul oleh diabetes melitus sebesar 22\%. Berdasarkan jenis kelamin presentasinya tidak jauh berbeda antara laki-laki (44,7\%) dan perempuan $(55,3 \%)$. Hal ini juga sama dengan IRR tahun 2016 bahwa terdapat 54,7\% pasien hemodialisis berjenis kelamin laki-laki sedangkan perempuan 45,3\%. Hasil uji statistik menunjukkan tidak ada perbedaan yang signifikan jenis kelamin dengan ketahanan hidup pasien PGK, sama dengan penelitian Rolim yang menjelaskan bahwa tidak ada pengaruh jenis kelamin terhadap ketahanan hidup pasien PGK yang menjalani hemodialisis. ${ }^{13}$ Karakteristik jenis kelamin tidak didapatkan perbedaan signi-fikan, dimana pasien laki-laki ketahanan hidupnya tidak berbeda dengan pasien perempuan, sama dengan hasil penelitian Yulianto dan Notobroto, pada karakteristik jenis kelamin ti-dak didapatkan perbedaan signifikan dimana pasien laki-laki ketahanan hidupnya tidak berbeda dengan pasien perempuan. ${ }^{14}$ Penelitian Roman, dkk menunjukan bahwa risiko yangsama pada jenis kelamin laki-laki 2,9 bulan sedangkan perempuan 1,9 bulan. ${ }^{6}$

Berdasarkan hasil penelitian, umur responden yang kurang dari 60 tahun sebesar $76,1 \%$ sedangkan yang berumur lebih dari 60 tahun 23,9\%, hal ini terjadi pergeseran usia dimana pasien PGK didominasi oleh usia kurang dari 60 tahun. Hal ini sama dengan penelitian yang dilakukan Aisyara dan bahwa kelompok umur tertinggi yaitu 40-60 tahun sebanyak 65 pasien $(62,5 \%), 15$ berbeda dengan laporan IRR bahwa terdapat 55\% pada usia kurang dari 55 tahun dan 45\% pada usia diatas 55 tahun. Hasil uji cox regression tidak ada pengaruh umur dengan ketahanan hidup pasien PGK, pertambahan usia akan memengaruhi anatomi, fisiologi dan sitologi pada ginjal. Setelah usia 30 tahun, ginjal akan mengalami atrofi dan ketebalan kortek ginjal akan berkurang sekitar 20\% setiap dekade dengan bertambahnya usia berupa penebalan membran basal glomerulus, ekspansi mesangium glomerular dan terjadinya deposit protein matriks ekstraselular sehingga menyebabkan glomerulosklerosis. ${ }^{16}$ Menurut Valdivia, dkk usia lebih dari 60 mempunyai ketahanan hidup pasien dengan usia tua sangat rendah. Semakin bertambahnya usia, semakin berkurang fungsi ginjal dan berhubungan dengan penurunan ke- 
cepatan ekskresi glomerulus dan memburuknya fungsi tubulus. ${ }^{17}$

Kadar hemoglobin tidak mempunyai pengaruh dengan lama ketahanan hidup pasien PGK dengan Hemodialisis $p=0,567$, hal ini sama dengan penelitian Ekantari bahwa tidak ada hubungan antara anemia dengan kematian pasien gagal ginjal kronik. Anemia banyak dijumpai pada pasien gagal ginjal kronik.18 Anemia terjadi pada awal perkembangan penyakit gagal ginjal yang mengakibatkan fungsi ginjal memburuk. Anemia telah dikaitkan dengan morbiditas substansial dan sampai kematian. $^{2}$

Hasil analisis perbedaan ketahanan hidup kelompok diabetes melitus dan tidak diabetes melitus dengan uji cox regression, hasil yang diperoleh $p=0,001$, dengan $\alpha=0,05$. Kelompok tidak diabetes melitus memiliki ketahanan hidup 2,3 kali lebih tinggi dibandingkan kelompok diabetes melitus, kelompok tidak diabetes melitus memiliki waktu yang lebih lama untuk hidup dibandingkan dengan kelompok diabetes melitus. Penelitian ini sejalan dengan penelitian yang dilakukan Arifa, Azam dan Handayani menunjukan bahwa responden dengan diabetes melitus berisiko 4,03 kali berpeluang lebih tinggi menderita PGK dibandingkan yang tidak diabetes melitus. ${ }^{16}$ Penelitian ini juga sejalan dengan peneitian Hengkesa dan Violan bahwa responden dengan diabetes melitus berisiko 5,134 kali berpeluang lebih tinggi menderita PGK dibandingkan yang tidak diabetes melitus. ${ }^{19}$
Faktor risiko diabetes melitus mempunyai risiko terhadap kejadian gagal ginjal kronik 4,1 kali lebih besar dibandingkan dengan pasien tanpa riwayat penyakit faktor risiko diabetes melitus. Diabetes melitus merupakan penyebab utama PGK di Amerika Serikat, dengan perkiraan menunjukkan hal itu hampir 50\% pasien diabetes menunjukkan bukti PGK, diabetes juga seringkali sulit untuk mengendalikan populasi PGK, beberapa agen antihyperglycemic merupakan kontraindikasi pada pasien PGK dan farmakokinetik yang lain, termasuk insulin, berubah dengan penurunan laju filtrasi glomerulus (GFR). ${ }^{20}$ Salah satu akibat dari komplikasi diabetes melitus adalah penyakit mikrovaskuler, diantaranya nefropati diabetika yang merupakan penyebab utama gagal ginjal terminal. Studi yang dilakukan di india penyakit gagal ginjal yang disertai dengan diabetes melitus menjadi penyebab utama mortalitas dan mordibitas. ${ }^{21}$ Berbagai teori tentang patogenesis nefropati seperti peningkatan produk glikosilasi dengan proses non-enzimatik yang disebut AGEs (Advanced Glucosylation End Products), peningkatan reaksi jalur poliol (polyol pathway), glukotoksisitas, dan protein kinase $\mathrm{C}$ memberikan kontribusi pada kerusakan ginjal. 22

\section{KESIMPULAN DAN SARAN}

Responden sebanyak 159 bahwa terjadi kematian (event) sebesar 47\% sedangkan yang hidup terdapat $27,3 \%$ pasien PGK dengan penyakit penyerta diabetes melitus, ketahanan hidup pasien $p=0,001$, dimana kelompok tidak diabetes melitus memiliki ketahanan hidup 2,3 
kali lebih tinggi dibandingkan kelompok yang mengalami diabetes melitus. Kelompok tidak diabetes melitus memiliki waktu yang lebih lama untuk hidup dibandingkan dengan kelompok diabetes melitus. Sedangkan untuk variabel covariat tidak ada pengaruh terhadap ketahanan pasien PGK yang menjalankan hemodialisis. Bagi pasien gagal ginjal kronik yang sudah memiliki penyakit penyerta diabetes disarankan untuk melakukan konsultasi dengan ahli gizi untuk diet rotein, menjaga kesehatan dengan melalukan aktifitas fisik dan sering melakukan check-up untuk mengontrol kadar gula dalam darah dan memberikan edukasi kepada pasien gagal ginjal terkait faktor risiko dari penyakit diabetes melitus, yang dapat menyebabkan kematian.

\section{UCAPAN TERIMA KASIH}

Ucapan terimakasih kepada Rumah Sakit Umum Darah Abdoel Moeloek Bandar Lampung yang telah memberikan ijin untuk penelitian Lembaga Penelitian dan Pengabdian Masyarakat Universitas Malahayati Bandar Lampung dan selalu memberikan dukungan pada penelitian ini.

\section{REFERENSI}

1. Antimas N, Lestari H, Ismail C. Survei Faktor Risiko Penyakit Tidak Menular pada Mahasiswa Universitas Halu Oleo Tahun 2017. Jurnal Ilmiah Mahasiswa Kesehatan Masyarakat. 2017;2(6):1-13.

2. Indonesian Renal Registry. Report of Indonesian Renal Registry. [Online]. Tim Indonesian Renal Registry; 2018.

3. Dada SA, Inubile, Thomas, Dada OE, Akinyemi RO. Survival Pattern of Patients on Maintenance Haemodialysis for End Stage Renal Disease in a Nigerian Dialysis
Centre. Archives of Nephrology and Urology. 2019;2(1):1-12.

4. Kemenkes RI. Situasi Penyakit Ginjal Kronis. Jakarta: Kementerian Kesehatan RI; 2017.

5. Hanum R, Nurhayati S, N Hasneli Y. Pengaruh Pendidikan Kesehatan Secara Individual tentang Pembatasan Asupan Cairan terhadap Pengetahuan Tentang Pembatasan Cairan dan IDWG (Interdialytic Weight Gain) pada Pasien Hemodialisis. Jurnal Online Mahasiswa Program Studi Ilmu Keperawatan Universitas Riau. 2015;2(2):1426-1434.

6. Schwaighofer RR, Kainz A, Kammer M, Dumfarth A, Oberbauer R. Survival Analysis of Conservative vs. Dialysis Treatment of Elderly Patients with CKD Stage 5. Plos One. 2017;12(7):1-10.

7. Ruiu DC, Moța E, Istrate N, Văduva C, Trican E. Renal Anemia - Risk Factor for Chronic Kidney Disease. Current Health Sciences Journal. 2013;39(4):214-217.

8. Indonesian Renal Registry. Report of Indonesian Renal Registry. [Online]. Tim Indonesian Renal Registry; 2016.

9. Umami V, Lydia A, Nainggolan G, Setiati S. Pengembangan Model Prediksi Mortalitas 3 Bulan Pertama pada Pasien Penyakit Ginjal Kronik yang Menjalani Hemodialisis. Jurnal Penyakit Dalam Indonesia. 2015;2(3):170182.

10. Ghonemy TA, Farag SE, Soliman SA, ElOkely A, El-Hendy Y. Epidemiology and Risk Factors of Chronic Kidney Disease in the El-Sharkia Governorate, Egypt. Saudia Journal of Kidney Diseases and Transplantation. 2016;27(1):117-117.

11. Triyanto E, Isworo A, Rahayu E. Model Pemberdayaan Terpadu untuk Meningkatkan Kepatuhan Pasien Diabetes Mellitus. Media Kesehatan Masyarakat Indonesia. 2015;1(1):228-324.

12. Mousavi B. Long-Term Survival of Patients with End-Stage Renal Disease on Maintenance Hemodialysis: a Multicenter Study in Iran. Iran Journal of Kidney Diseases. 2012;6(6):452-456. 
13. Rolim FI, Santos RF. Survival of Hemodialysis Patients at a University Hospital. Brazilian Journal of Nephrology. 2014;37(1):64-71.

14. Yulianto D, Basuki H. Analisis Ketahanan Hidup Pasien Penyakit Gagal Ginjal Ginjal Kronis dengan Hemodialisis di RSUD Dr. Soetomo Surabaya. Jurnal Manajemen Kesehatan Yayasan RS Dr. Soetomo. 2017;3(1):96-108.

15. Aisara S, Azmi S, Yanni M. Gambaran Klinis Penderita Penyakit Ginjal Kronik yang Menjalani Hemodialisis di RSUP Dr. M. Djamil Padang. Jurnal Kesehatan Andalas. 2018;7(1):42-50.

16. Arifa SI, Azam M, Handayani OWK. Faktor yang Berhubungan dengan Kejadian Penyakit Ginjal Kronik Pada Penderita Hipertensi di Indonesia. Media Kesehatan Masyarakat Indonesia. 2017;13(4):319328.

17. Valdivia J, Gutiérrez C, Treto J, Delgado E, Méndez $D$, et al. Prognostic Factors in Hemodialysis Patients: Experience of a Havana Hospital. MEDICC Review. 2013;15(3):11-15.
18. Ekantari F. Hubungan antara Lama Hemodialisis dan Faktor hubungan Komorbiditas dengan Kematian Pasien Gagal Ginjal Kronik di RSUD Dr. Moewardi. [Skripsi]. Surakarta: Universitas Muhammadiyah Surakarta; 2012.

19. Hengkesa P, Lawalata IV. Faktor Risiko Penyakit Ginjal Kronik. Jurnal Molluca Medica. 2015;8(1):72-81.

20. Lovre D, Shah S, Sihota A, Fonseca VA. Managing Diabetes and Cardiovascular Risk in Chronic Kidney Disease Patients. Endocrinology and Metabolism Clinics of North America. 2018;47(1):237-257.

21. Vijayan M, Radhakrishnan S, Abraham G, Mathew M, Sampathkumar K, Mancha NP. Diabetic Kidney Disease Patients on Hemodialysis: A Retrospective Survival Analysis Across Different Socioeconomic Groups. Clinical Kidney Journal. 2016;9(6):833-838.

22. Pranandari R, Supadmi W. Faktor Risiko Gagal Ginjal Kronik di Unit Hemodialisis RSUD Wates Kulon. Majalah Farmaseutik. 2015;11(2):316-320. 